I. П. Мажара

Харківський національний університет Повітряних Сил імені Івана Кожедуба, Харків, Україна

\title{
МЕТОД ПРИЙНЯТТЯ РІШЕННЯ 3 ФОРМУВАННЯ ПОТОКІВ ЛІТАКІВ ДЛЯ ЗАХОДУ НА ПОСАДКУ З ВИКОРИСТАННЯМ НЕЧІТКИХ НЕЙРОМЕРЕЖЕВИХ ТЕХНОЛОГІЙ
}

\begin{abstract}
Анотація. Розглядається метод прийняття рішення 3 формування потоків літаків для заходу на посадку 3 використанням нечітких нейромережевих технологій. Подано схему процесу управління повітряним рухом керівника польотів в зоні візуального контролю. Визначені основні схеми формування потоків літаків для заходу на посадку, сформована множина правил яка $\epsilon$ початковою базою правил. для кожного прикладу, отриманого при формуванні навчальної вибірки за результатами прогнозування варіанту формування потоку літаків, визначаються нечіткі ступені приналежності заданих значень лінгвістичної змінної до відповідних $F O U$, кожному навчальному прикладу ставляться у відповідність IHМТ2, нечіткі ступені приналежності до яких у відповідних значеннях лінгвістичних змінних є максимальними. Мета статті: удосконалення методу прийняття рішення 3 формування потоків літаків для заходу на посадку з використанням нечітких нейромережевих технологій.

Ключові слова: формування потоків літаків, управління повітряним рухом, група керівництва польотами, лінгвістична змінна, інтервальна нечітка множина другого типу.
\end{abstract}

\section{Вступ}

Постановка проблеми. Основною метою розпізнавання варіанту формування потоків літаків (ФПЛ) для заходу на посадку при повернені на аеродром після виконання бойового завдання $є$ віднесення їх формалізованих описів до відповідних класів. Автоматизація процедур розпізнавання $\epsilon$ елементом автоматизації прийняття рішень. За результатами розпізнавання бойових порядків повітряних суден приймають рішення щодо виконання маневрів для побудови єдиного потоку повітряних суден для посадки з метою попередження зіткнень та економічної витрати палива [1].

Специфіка діяльності осіб групи керівництва польотами (ГКрП) при вирішенні завдання управління повітряним рухом, а саме різні підходи до їі вирішення, одночасне вирішення кількох завдань, створює навантаження на дії осіб групи керівництва польотами [1-3].

Тому, актуальним $\epsilon$ напрямок досліджень роботи осіб групи керівництва польотами, пов'язаний 3 розробкою інформаційної системи управління повітряним рухом (УПР). Вона дозволяє інтегрально оцінювати різні показники якості їх діяльності з використанням автоматизованих робочих місць.

Аналіз літератури. Теоретичні та методологічні питання побудови інтелектуальної системи досить повно викладені в [4-6]. Формування інформаційної системи в аналогічній системі контролю за порядком використання повітряного простору розглянуті в [7-8]. Ці та інші роботи в аналізованої предметної області базуються на припущенні, що інформаційні ознаки, що підлягають відображенню, є відомими. Однак питання безпосереднього розпізнавання варіантів ФПЛ з використанням методів інтервальної нечіткої множини другого типу(IHМT2) і нечіткої логічної системи інтервального типу 2 (НЛС IT2) в даній літературі не розглядаються [9-10]. У [11-16] розглянуті питання автоматизації процесів вироблення рішень в системах уп- равління. У [17;18] розроблено формалізований опис знань про процес визначення напрямків головного удару засобів повітряного нападу противника, але без урахування можливих видів невизначеності цих знань.

Проблема удосконалення професійної підготовки осіб ГКрП, в тому числі з використанням інформаційної системи управління повітряним рухом для формування умінь і навичок в складній обстановці, залишається недостатньо дослідженою. Дана система дозволить аналізувати, контролювати й інтегрально оцінювати різні показники якості діяльності осіб групи керівництва польотами.

Мета статті. Удосконалення методу прийняття рішення з формування потоків літаків для заходу на посадку з використанням нечітких нейромережевих технологій.

\section{Виклад основного матеріалу}

При побудові нечіткої нейронної мережевої моделі процесу УПР необхідно досліджувати надійність роботи кожної особи ГКрП щодо формування потоків літаків у своїй зоні відповідальності, у т.ч. 3 урахуванням виникнення нештатних ситуацій у повітрі і на землі [19-21].

Щоб не ускладнювати саму нейронну мережу і не збільшувати час iï навчання, зупинимося на досліджуванні надійності роботи керівника польотів у зоні візуального контролю. Саме в цій зоні акумулюється вся інформація про повітряну і наземну обстановку. Крім того, керівник польотів займає центральне місце у складі ГКрП.

Схема процесу УПР фактично являє послідовний контроль за повітряними суднами (ПС) на різних етапах польоту (рис. 1). При плануванні УПР необхідно співвідносити задане місце розташування ПС $з$ фактичним.

Джерело: розроблено автором за даними [22; 23].Позиція 1. У встановлену годину плановою таблицею керівник польотів дозволяє запуск двигунів, особисто управляє рухом літаків у процесі руління. 
5 ПОСАДКА

- дозвіл

- ЗПС вільна

- U, V вітру відповідає;

- контроль глісади та

напрямку на зПС;

- вирівнювання.

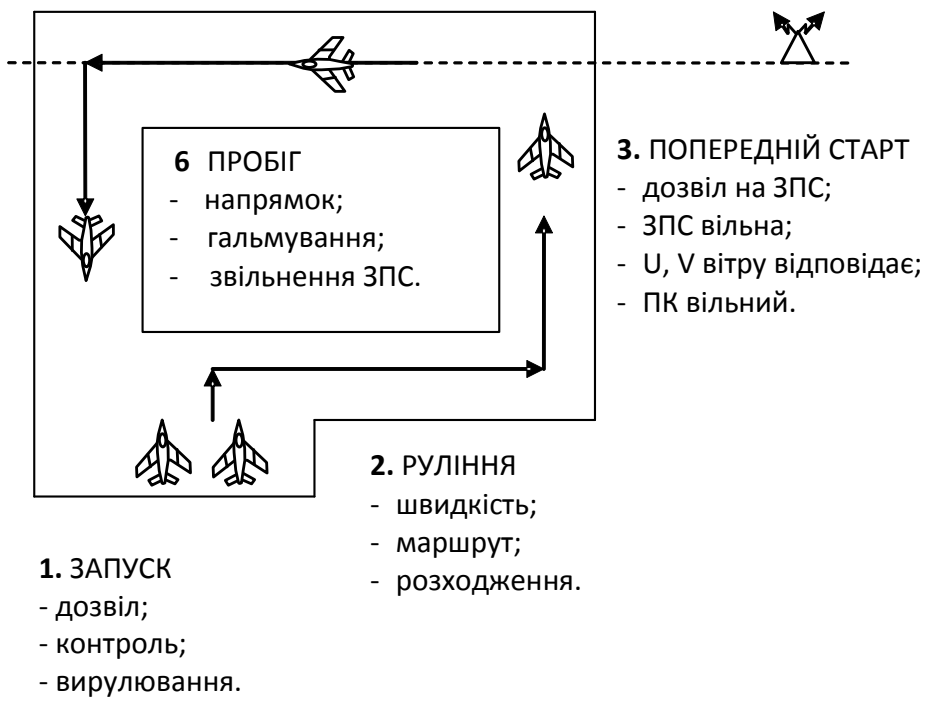

Рис. 1. Схема процесу управління повітряним рухом керівника польотів в зоні візуального контролю (джерело: розроблено автором за даними [22; 23])

Позиція 2. У процесі руління керівник польотів стежить за витримкою швидкості руху, маршруту і розходження з іншими ПС та перешкодами.

Позиція 3. Після доповіді льотчика про готовність до зльоту дозволяє (забороняє) зліт (по радіо або світлофорами) і контролює рух літака від початку розгону до виходу за межі візуальної видимості. При цьому увага звертається на витримку напряму розгону, створення злітного кута, витримку бойового порядку в групі, кута набору висоти, прибирання шасі.

Позиція 4. При відхиленнях у процесі зльоту, а тім більш при виникненні аварійної ситуації, керівник польотів повинен уміти миттєво оцінювати ситуацію, швидко й грамотно ухвалювати рішення й діяти рішуче. При зльоті літака керівник польотів повинен безперервно стежити за ним, не відволікаючись на рішення інших питань.

Позиція 5. Після доповіді льотчика про прохід радіомаяка керівник польотів переконується в тому, що ЗПС вільна, і дає дозвіл на посадку. По можливості візуально знаходить літак, по сигналізації (доповіді) від спостерігаючого за шасі переконується в ix випуску й контролює глісаду зниження, напрям заходу й виконання посадки, надаючи при необхідності льотчику допомогу.

Позиція 6. У процесі пробігу керівник польотів стежить за витримкою напряму, випуску гальмівного парашута й процесом гальмування. Якщо парашут не вийшов (не наповнився) або обірвався, негайно попереджає про це льотчика й дає команду на більш ефективне використовування гальмівної системи літака. Після закінчення пробігу контролює звільнення злітно-посадкової смуги (ЗПС), скидання гальмівного парашута й зарулювання літака на стоянку.

Особливо складним елементом в УПР $є$ формування потоку літаків. Це пояснюється тим, що це відбувається в зоні ЗПС, яка має обмежену пропускну здатність, що залежить від таких факторів:

- характеристик елементів льотного поля;

- метеорологічних умов;

- посадочних систем, які використовуються;

- льотно-технічних характеристик ПС;

- встановлених норм ешелонування;

- організації руху ПС у зоні зльоту і посадки.

Зазвичай кілька факторів $є$ неявними. Тому у процесі вдосконалення моделі виділяють певний набір критеріїв, який може доповнюватися. Він не впливає на саму систему, але якісно покращує “портрет" об'єкта дослідження.

Потім складають правила нечітких продукцій виду IF-THEN взаємодії виявлених чинників. Формуються вибірки для навчання нечіткої нейронної мережі.

Далі, грунтуючись на знаннях експертів визначаються варіанти формування потоку літаків при використанні ЗПС, а також кількість і значимість факторів, що впливають на ФПЛ.

Найбільш складним варіантом ФПЛ за технологічною процедурою при використанні ЗПС є “посадка після зльоту". На відміну від варіантів “зліт після зльоту” i “зліт після посадки”, коли керівник польотів може затримати ПС, яке злітає, на будь-який необхідний час, у процедурі “посадка після зльоту” керівник польотів повинен абсолютно точно розрахувати 
всі часові інтервали для забезпечення безпеки польотів. При виконанні процедури “посадка після посадки” інтервал між літаками забезпечують керівник ближньої зони і керівник зони посадки.

Таким чином, визначені основні схеми ФПЛ. Кожна 3 них характеризується певною кількістю факторів, що впливають на ефективність як окремого процесу-блоку, так і всього УПР в цілому. Фактори, що впливають та їх значимість, визначаються, в основному, з міркувань і досвіду експертів.

Формальне представлення прогнозованих варіантів ФПЛ як сукупності нечітких продукційних правил або формування бази правил для кожного можливого варіанту ФПЛ у рамках розробленого методу здійснюється за результатами формування описів класів згідно з виразами $(1,2)$ :

$$
\begin{aligned}
& M_{\text {nос }(\text { oj })}^{t} \geq M_{\text {зад(o) }} ; \\
& \left\{\beta^{N^{P}}, \beta^{Q^{P}}, \beta^{L^{P}}, \beta^{H^{P}}, \beta^{Z^{P}}\right\},
\end{aligned}
$$

де лінгвістичні змінні (ЛЗ) мають такі найменування: “кількісний склад бойових порядків"; “напрям заходу на посадку”; “ширина розпуску бойових порядків"; “глибина розпуску бойових порядків”; “значимість ПС, щодо першочерговості заходу” відповідно (2). При цьому використовуються правила нечітких продукцій $R$ :

$$
c_{j}^{p}=\left\langle\begin{array}{c}
F O U\left(\tilde{A}_{\Pi i}^{N^{P}}\right), F O U\left(\tilde{A}_{\Delta q}^{Q^{P}}\right), F O U\left(\tilde{A}_{\Pi l}^{L^{P}}\right), \\
F O U\left(\tilde{A}_{\Pi h}^{H^{P}}\right), F O U\left(\tilde{A}_{\Delta k}^{Z^{P}}\right)
\end{array}\right\rangle .
$$

3 погляду математичної формалізації, нечітке продукційне правило, представлене виразом

$$
c_{j}^{p}=\left\langle\alpha_{i}^{N^{P}}, \alpha_{q}^{Q^{P}}, \alpha_{l}^{L^{P}}, \alpha_{h}^{H^{P}}, \alpha_{k}^{Z^{P}}\right\rangle,
$$

де $\tilde{A}_{П i}^{N^{P}}$ - THI IHМТ2, що представляє дані про кількісний склад ПС в ј-му бойовому порядку й описує можливі значення відповідної Н3 $\alpha_{i}^{N^{P}} ; \tilde{A}_{\Delta q}^{Q^{P}}$ ТНЧ ІНМТ2, що представляє дані про напрям заходу на посадку ј-го бойового порядку й описує можливі значення відповідної Н3 $\alpha_{q}^{Q^{P}} ; \tilde{A}_{\Pi l}^{L^{P}}-\mathrm{THI}$ IHМT2, що представляє дані про ширину розпуску јго бойового порядку й описує можливі значення відповідної Н3 $\alpha_{l}^{L^{P}} ; \tilde{A}_{П h}^{H^{P}}-$ THI IHMT2, що представляє дані про глибину розпуску ј-го бойового порядку й описує можливі значення відповідної НЗ $\alpha_{h}^{H^{P}} ; \tilde{A}_{\Delta k}^{Z^{P}}-$ ТНЧ ІНМТ2, що представляє дані про значимість ј-го бойового порядку й описує можливі значення відповідної нечіткої змінної (Н3).

Дане нечітке продукційне правило (3) розглядається як нечітка імплікація вигляду [24 - 26]:

$$
\tilde{A} \rightarrow \tilde{B} .
$$

де $\tilde{A} \subseteq X$ и $\tilde{B} \subseteq Y-$ ІНМТ2, що представляють відповідно умову і заключення (що описують можливі значення НЗ). При цьому $\tilde{B}$ являє собою одноточкову IНМТ2, для якої $\mu_{\tilde{B}}(y)=1$ (при представленні ІНМТ2 способом вертикального срізу), $X$ область визначення умови (у загальному випадку $X=X_{1} \times X_{2} \times \ldots \times X_{n}$ i $\left.\tilde{A}=\tilde{A}_{1} \times \tilde{A}_{2} \times \ldots \times \tilde{A}_{n}\right), Y-$ область визначення заключення (номера класів із множини $\left.C_{p}=\left\{c_{j}^{p}\right\}\right)$.

Мінімальна кількість сформованих нечітких продукційних правил відповідно до (3), (4), відповідає потужності множини можливої кількості ПС, які одночасно знаходяться у повітрі $\operatorname{card} C_{p}=\left|C_{p}\right|=m$, прогнозованих у плановій таблиці у ході підготовки до виконання бойового завдання. Тоді нечітке продукційне правило, що визначає приналежність варіанту ФПЛ до класу $c_{j}^{p}$, матиме такий вигляд у двох варіантах формального представлення:

$$
\begin{gathered}
\left(R_{j}: \text { if } \beta^{N^{P}} \text { is } \alpha_{i}^{N^{P}} \text { and } \beta^{Q^{P}} \text { is } \alpha_{q}^{Q^{P}} \text { and } \beta^{L^{P}} \text { is } \alpha_{l}^{L^{P}}\right) \\
\&\left(\beta^{H^{P}} \text { is } \alpha_{h}^{H^{P}} \text { and } \beta^{Z^{P}} \text { is } \alpha_{k}^{Z^{P}} \text { then } \beta^{N G U}=c_{j}^{p}\right) \\
R_{j}: \tilde{A}_{\Pi i}^{N^{P}} \times \tilde{A}_{\Delta q}^{Q^{P}} \times \tilde{A}_{\Pi l}^{L^{P}} \times \tilde{A}_{\Pi h}^{H^{P}} \times \tilde{A}_{\Delta k}^{Z^{P}} .
\end{gathered}
$$

3 метою забезпечення повноти початкової бази правил (БП) про розпізнавання варіанту ФПЛ:

- для кожного прикладу, отриманого при формуванні навчальної вибірки за результатами прогнозування варіанту ФПЛ, визначаються нечіткі ступені приналежності заданих значень ЛЗ до відповідних FOU ;

- кожному навчальному прикладу ставляться у відповідність ІНМТ2, згідно з виразами (8) - (11), нечіткі ступені приналежності, до яких у відповідних значеннях ЛЗ $є$ максимальними.

$$
T^{N^{P}}=\left\{\begin{array}{l}
\alpha_{1}^{N^{P}}=\text { "меньше } n_{r}^{11}, n_{r}^{12} \Pi C^{\prime \prime}, \\
\alpha_{2}^{N^{P}}=\text { "в діапазоні } n_{l}^{21}, n_{l}^{22}-n_{r}^{21}, n_{r}^{22} \Pi C^{\prime \prime}, \\
\ldots, \\
\alpha_{N-1}^{N^{P}}=\text { "в діапазоні } n_{l}^{(N-1) 1}, n_{l}^{(N-1) 2}-n_{r}^{(N-1) 1}, \\
n_{r}^{(N-1) 2} \Pi C^{\prime \prime}, \\
\alpha_{N}^{N^{P}}=\text { "більше } n_{r}^{N 1}, n_{r}^{N 2} \Pi C^{\prime \prime},
\end{array}\right\}
$$

де $\alpha_{i}^{N^{P}}-\mathrm{H3}$, що описує можливий кількісний діапазон ПС, що заходять на посадку $i=1, \ldots, N$.

$$
T^{Q^{P}}=\left\{\begin{array}{l}
\alpha_{1}^{Q^{P}}=\text { "1- й напрямок" } \\
\cdots \\
\alpha_{M}^{Q^{P}}=" M-\text { й напрямок" }
\end{array}\right\},
$$


де $\alpha_{q}^{Q^{P}}-\mathrm{H} 3$, що описує можливий діапазон напрямів заходу на посадку $q=1, \ldots, M$.

$$
T^{L^{P}}=\left\{\begin{array}{c}
\alpha_{1}^{L^{P}}=\text { "менше } n_{r}^{11}, n_{r}^{12} \kappa M^{\prime \prime}, \\
\alpha_{2}^{L^{P}}=\text { "в діапазоні } n_{l}^{21}, n_{l}^{22}-n_{r}^{21}, n_{r}^{22} \text { км", } \\
\quad \cdots, \\
\alpha_{L-1}^{L^{P}}=\text { "в діапазоні } n_{l}^{(L-1) 1}, n_{l}^{(L-1) 2}-n_{r}^{(L-1) 1}, \\
n_{r}^{(L-1) 2} \text { км", } \\
\alpha_{L}^{L^{P}}=\text { "більше } n_{r}^{L 1}, n_{r}^{L 2} \text { км", }
\end{array}\right\}
$$

де $\alpha_{l}^{L^{P}}-\mathrm{H} 3$, що описує можливий діапазон значень ширини розпуску бойових порядків ПС $l=1, \ldots, L$;

$$
T^{H^{P}}=\left\{\begin{array}{l}
\alpha_{1}^{H^{P}}=\text { "менше } n_{r}^{11}, n_{r}^{12} \kappa \mu^{\prime \prime}, \\
\alpha_{2}^{H^{P}}=\text { "в діапазоні } n_{l}^{21}, n_{l}^{22}-n_{r}^{21}, n_{r}^{22} \kappa \mu^{\prime \prime}, \\
\alpha_{H-1}^{H^{P}}=\text { "в діапазоні } n_{l}^{(H-1) 1}, \\
n_{l}^{(H-1) 2}-n_{r}^{(H-1) 1}, n_{r}^{(H-1) 2} \kappa \mu^{\prime \prime}, \\
\alpha_{L}^{H^{P}}=\text { "більше } n_{r}^{H 1}, n_{r}^{H 2} \kappa \mu^{\prime \prime},
\end{array}\right\}
$$

де $\alpha_{h}^{L^{P}}-\mathrm{H} 3$, що описує можливий діапазон значень глибини розпуску бойових порядків ПС $h=1, \ldots, H$.

Сформована так само множина правил у вигляді виразів (6), (7) є початковою БП. Дані правила формуються для кожного прогнозованого варіанту ФПЛ. Надалі вони є вхідними даними методу формалізації знань про виявлення і розпізнавання варіантів ФПЛ на основі нечітких класифікаторів.

Таким чином для забезпечення несуперечності БП полягає в тому, щоб не допустити в процесі формування нечітких продукційних правил випадків, коли одна і та ж сама комбінація термів ЛЗ приводить до визначення різних варіантів ФПЛ. Порядок виконання операцій із забезпечення несуперечності БП для розпізнавання варіантів ФПЛ аналогічний порядку виконання операцій із забезпечення несуперечності БП для розпізнавання складних (групових) об'єктів.

\section{Висновки}

У роботі розглянуто метод прийняття рішення 3 формування потоків літаків для заходу на посадку 3 використанням нечітких нейромережевих технологій. Розроблено схему інформаційної системи процесу УПР, що описує формування потоку літаків у зоні візуального контролю в умовах невизначеності і з урахуванням впливу на процес нечітких факторів. Визначені реальні схеми ФПЛ, в кожній з яких виділяються значущі фактори, що впливають на ефективність як окремого блоку-процесу, так і управління повітряним рухом в цілому. Для визначення схем ФПЛ, кількості факторів, які впливають на процес та їх значимості у використані знань і досвіду експертів, які здійснюють реальне керівництво польотами на аеродромах Збройних Сил України.

Отримав подальший розвиток метод формалізації знань про прогнозовані варіанти ФПЛ, в якому, на відміну від відомих, розроблений апарат формалізації побудовано на основі гібридної нечіткої нейронної мережі, що реалізує нечіткі операції над інтервальними нечіткими множинами другого типу і $є$ ізоморфною початковій базі нечітких продукційних правил. Навчальна вибірка для визначення початкової бази правил формується за результатами використання взаємопов'язаних часткових математичних моделей прогнозування варіантів ФПЛ. Це дозволяє автоматизувати процес формування початкової бази правил шляхом співставлення кожного прикладу із вибірки відповідному окремому правилу; врахувати невизначеність лінгвістичних та інтервальнооцінюваних параметрів прогнозованих варіантів ФПЛ з використанням інтервальних нечітких множин другого типу; усунути суб'єктивність при виборі виду і параметрів функцій приналежності у нечітких висловлюваннях правил, а також забезпечити можливість автоматичного набуття знань шляхом навчання гібридної нечіткої нейронної мережі та розпаралелити обчислення з реалізацією відповідного алгоритму навчання на графічних процесорах.

\section{,СПИСОК ЛІТЕРАТУРИ}

1. Мажара І.П., Тимочко О.І., Чернов В.Г. Інформаційна модель допуску осіб групи керівництва польотами до управління повітряним рухом. Наука і техніка Повітряних Сил Збройних Сил України. 2018. № 1(30). С. 24 - 29.

2. Мажара І.П., Тимочко О.І. Модель інформаційної системи управління повітряним рухом з точки зору операторської діяльності осіб групи керівництва польотами. Системи озброєння і військова техніка. 2021. № 1(65). С. $12-17$.

3. Степанов Г.С., Камінський В.В, Павленко М.А. Погляди щодо проблемних питань застосування Повітряних Сил в протиповітряній обороні. Наука і техніка Повітряних Сил Збройних Сил Украӥни. 2018. № 1(30). С. 18 - 23.

4. Джума Л.Н., Неделько В.Н., Пилипёнок О.Н., Хох В.Д. Интеллектуальная обучающая система как средство повышения эффективности процессов управления воздушным движением. Научные записки Украинского научноисследовательского института связи. К.: Украинский НИИ связи, 2015. № 6(40). С. 49 - 55.

5. Павленко М.А. Методы и процедуры отбора операторов АСУ при использовании интеллектуальных систем поддержки принятия решений. Збірник наукових пращь ХУПС. Вип. 4 (33). Х. : ХУ ПС, 2012. С. 171-177.

6. Герасимов Б.М. Інтелектуальні системи підтримки прийняття рішень: навч. пос. / Б.М. Герасимов, В.М. Локазюк, О.Г. Оксіюк, О.В. Поморова. - К.: Вид-во Європ. ун-ту, 2007. - 335 с.

7. Павленко М.А., Бердник П.Г., Хромов И.Ю. Метод анализа деятельности оператора автоматизированных систем управления воздушным движением. Системи обробки інформації. Х.: ХУ ПС, 2007. Вип. 1(59). С. 78-81

8. Олизаренко С.А. Нечеткие множества типа 2. Терминология и представление / С.А. Олизаренко, Е.В. Брежнев, А.В. Шрепелица // Системи обробки інформації. - 2010. - № 8(89). - С. 131-140. 
9. Неделько В.Н. Обеспечение зффективности информационной поддержки принятия решений в автоматизированных системах обслуживания воздушного движения с злементами искусственного интеллекта: дис. ... канд. техн. наук: 05.22.13 /В.Н. Неделько. - К., 2002. - 183 с.

10. Олизаренко С.А. Интервальные нечеткие множества типа 2. Терминология, представление, операции / С.А. Олизаренко, А.В. Шрепелица, В.А. Капранов // Системи обробки інформації. - 2011. - № 2(92). - С. 39-45.

11. Ярушек В.Е. Теоретические основы автоматизации процессов выработки решений в системах управления / В.Е. Ярушек, В.П. Прохоров, А.В. Мишин, Б.Н. Судаков. - Х.: ХУПС, 2011. - 355 с.

12. Неділько С.М. Основи теорії функціональної стійкості автоматизованої системи управління повітряним рухом: монографія / С.М. Неділько. - Кіровоград: ДЛАУ, 2011. - 218 с.

13. Неділько С.М. Основи теорії функціональної стійкості автоматизованої системи управління повітряним рухом: монографія / С.М. Неділько. - Кіровоград: ДЛАУ, 2011. - 218 с.

14. Субботин С.А. Интеллектуальные информационные технологии проектирования автоматизированных систем диагностирования и распознавания образов: монографія / С.А. Субботин, А.А. Олейник, Е.А. Гофман. - Х.: Компания Смит, 2016. - $317 \mathrm{c}$.

15. Тимочко А.И. Моделирование деятельности лица, принимающего решения, в системах сетевого управления / А.И. Тимочко, М.А. Павленко, В.Н. Руденко // Радиотехника. Вып. 151. - Х.: МОНУ, ХНУРЕ, 2007. - С. 85-91.

16. Павленко М.А. Моделирование деятельности оператора с использованием CASE-технологий при разработке перспективных средств автоматизации. / М.А. Павленко // Системи обробки інформації. - Х.: ХУ ПС, 2009. - Вип. 6(80). C. 89-92.

17. Олизаренко С.А. Метод формализации задачи распознавания направлений ударов СВН противника на основе нечеткой классификации / С.А. Олизаренко, А.В. Перепелица, В.А. Капранов // Системи обробки інформації. - Х.: ХУПС, 2012. - Вип. 2(100). - С. 70-80.

18. Олизаренко С.А. Метод формализации задачи определения направлений ударов СВН противника на основе автоматической нечеткой классификации / С.А. Олизаренко, А.В. Перепелица, В.А. Капранов // Системи озброєння та військова техніка. - Х.: ХУПС, 2011. - Вип. 3(27). - С. 48-55.

19. Левченко, Н.Г. Оптимизация слабо формализованных процессов с использованием нечеткой нейронной модели / Н.Г. Левченко. // Журнал университета водных коммуникаций. - СПб.: СПГУВК, Выпуск 4 (16), 2012. - С. $105-114$.

20. Glushkov, S., Levchenko, N. Use of Neural Network Technologies for Improving Efficiency of Transport and Logistics Processes / N. Levchenko, S. Glushkov // Asia-Pacific Journal of Marine Science\&Education, Vol. 3, \# 1, 2013, pp 67-74.

21. Levchenko, N. The Imitating model of the maritime branch enterprise's information management system / N. Levchenko. // Asia-Pacific Journal of Marine Science\&Education, Vol. 1, \# 1, 2011, pp 107-112.

22. Управління польотами державної авіації України. Ч. 1.Правила польотів державної авіації в повітряному просторі України: навч. посіб. / О. І. Тимочко, І. П. Мажара, В. М. Сургай та ін. - Х. : ХНУПС, 2020. - 76 с.

23. Управління польотами державної авіації України, частина 2. Організація та порядок проведення польотів державної авіації України: навч. посіб./ В. Г. Чернов, І. П. Мажара,В. М. Сургай, та ін. - Х. : ХНУПС, 2018. - 76 с.

24. Mendel J.M. Type-2 fuzzy sets and systems: an overview. IEEE Computational Intelligence Magazine, 2007. Vol. 2. P. $20-29$.

25. Karnik N.N., Mendel J.M. Operations on type-2 fuzzy sets, Int. J. Fuzzy Sets Syst., 2001. - vol. 122. - pp. $327-348$.

26. Олизаренко С.А., Перепелица А.В., Капранов В.А. Нечеткие логические системы интервального типа 2. Архитектура и механизм вывода. Системи обробки інформації. Харків: ХУПС, 2011. Вип. 5 (95). С. 156 - 164.

Received (Надійшла) 23.04.2021

Accepted for publication (Прийнята до друку) 07.072021

\section{Decision-making method for formation of aircraft flows for landing using fuzzy neural network technologies}

\section{Mazhara}

Abstract. When constructing a fuzzy neural network model of the air traffic control process, it is necessary to investigate the reliability of each flight crew member in the formation of aircraft flows in their area of responsibility, taking into account the occurrence of abnormal situations in the air and on the ground. The purpose of the article: to improve the method of decisionmaking on the formation of aircraft flows for landing using fuzzy neural network technologies. Schemes of the air traffic con trol process is actually a sequential control of aircraft at different stages of flight. When planning air traffic, it is necessary to correlate the specified location of the aircraft with the actual one. Then make the rules of fuzzy products of the type IF-THEN interaction of the identified factors. Samples are formed to train a fuzzy neural network. Then, based on the knowledge of experts, the options for the formation of the flow of aircraft using the runway, as well as the number and significance of factors influencing the option of forming the flow of aircraft are determined. Thus, the basic schemes of formation of streams of planes are defined. Each of them is characterized by a number of factors that affect the efficiency of both the individual process unit and the entire air traffic as a whole. Influencing factors and their significance are determined mainly from the considerations and experience of experts. The method of formalization of knowledge about predicted formation of the flow of aircraft variants was further developed, in which, unlike the known ones, the developed formalization apparatus is built on the basis of a hybrid fuzzy neural network, which implements fuzzy operations on interval fuzzy sets of the second type and is isomorphic to the initial fuzzy production rules base. The training sample to determine the initial base of rules is formed based on the results of the use of interconnected partial mathematical models for predicting formation of the flow of aircraft variants. This allows you to automate the process of forming the initial base of rules by comparing each sample from the sample to the corresponding individual rule; take into account the uncertainty of linguistic and interval-estimated parameters of the predicted options for the formation of flows using interval fuzzy sets of the second type; eliminate subjectivity in choosing the type and parameters of membership functions in fuzzy statements of rules, and to enable the automatic acquisition of knowledge by learning a hybrid fuzzy neural network and parallelize calculations with the implementation of the appropriate algorithm for learning on graphics processors

Keywords: formation of aircraft flows, air traffic control, flight control groups, linguistic variable, interval fuzzy set of the second type. 